\title{
RANBP17 wt Allele
}

National Cancer Institute

\section{Source}

National Cancer Institute. RANBP17 wt Allele. NCI Thesaurus. Code 697755.

Human RANBP17 wild-type allele is located in the vicinity of $5 q 34$ and is approximately $438 \mathrm{~kb}$ in leng th. This allele, which encodes ran-binding protein 17, may be involved in the transport of molecules into or out of the nucleus. 